\title{
In vitro Efficacy of Different Botanicals and Fungicides on Brinjal Leaf Mold Pathogen
}

\author{
Prashant*, R.K. Tombisana Devi and N. Iboton Singh \\ Central Agricultural University, Imphal, Manipur, India \\ *Corresponding author
}

A B S T R A C T

\begin{tabular}{|c|c|}
\hline & \multirow{4}{*}{$\begin{array}{l}\text { Brinjal is an important vegetables crop grown in India. The leaf mold is an } \\
\text { important disease causing yield loss in Manipur region. Among the plant } \\
\text { extracts studied garlic at both concentrations ( } 3 \text { and } 6 \% \text { ) showed maximum } \\
\text { growth inhibition, whereas among the fungicides propiconazole and } \\
\text { hexaconazole showed the maximum efficiency in inhibition of growth over } \\
\text { the control. The sporulation was completely inhibited in all the treatments } \\
\text { studied. }\end{array}$} \\
\hline $\begin{array}{l}\text { Brinjal, Crop, } \\
\text { In vitro, Leaf mold. }\end{array}$ & \\
\hline Article Info & \\
\hline $\begin{array}{l}\text { Accepted: } \\
26 \text { August } 20 \\
\text { Available On } \\
10 \text { September }\end{array}$ & \\
\hline
\end{tabular}

\section{Introduction}

India is the second largest producers of brinjal next to China. The area under cultivation of brinjal in India is 680 ('000 ha), the yield being 12706 ('000 Tonne) (Anonymous, 2016).

The brinjal suffers from many diseases affecting roots, stem, leaves and fruits. The most common diseases are damping off (Pythium spp., Phytophthora spp., Rhizoctonia spp.), Phomopsis blight (Phomopsis vexans), Verticillium wilt (Verticillium dahliae), bacterial wilt (Ralstonia solanacearum), leaf mold (Cladosporium fulvum) etc.

The diseases leaf mold disease is now causing the considerable yield losses in Manipur state. The symptoms of the leaf mold disease are characterized by the appearance of brown cottony growth in patches on the abaxial side of the leaf and the patches become dark brown when the disease advances and all leads to defoliation (Prashant et al., 2017). Pandey and Pandey (2001) identified Cladosporium fulvum from diseased plants and fruits of aubergines. Mishra and Mishra (2012) reported that Cladosporium fulvum was present on both plant and fruit of eggplant and generally occurred during November to May.

There is little information on the management of this disease. Considering the importance of this disease, the experiment was conducted with the objective of analyzing the efficacy of different plant extracts and fungicides on fungus growth and sporulation in vitro. 


\section{Materials and Methods}

The research was conducted during 2014-15 in Department of Plant Pathology, College of Agriculture, CAU, Imphal, Manipur.

\section{Isolation and purification}

Diseased leaf samples were collected from the field and brought to the laboratory. The mold growth on the lower surface was scraped and aseptically transferred to potato dextrose agar (PDA) slants. These test tubes were incubated at $26 \pm 2{ }^{\circ} \mathrm{C}$ for the fungal growth. The fungal culture was purified by hyphal tip cut method (Tutte, 1969). The pure culture was maintained inside the refrigerator at $4^{0} \mathrm{C}$ and periodically sub cultured to fresh medium throughout the experimental period.

\section{Preparation of plant extracts}

Freshly collected plant parts were washed in running water for about $2 \mathrm{~min}$ then with sterile water. These plants were then air dried over a blotting paper. The air-dried plant parts were crushed separately in sterilized mortar and pestle with sterile distilled water separately at ratio $1: 1(\mathrm{w} / \mathrm{v})$.

These extracts were filtered through 2 folds muslin cloth and filtrates were centrifuged at $1500 \mathrm{rpm}$ for 15 minutes and the supernatants were collected. The extracts thus prepared were considered as $100 \%$ concentration.

The efficacy of 7 fungicides namely carbendazim $\quad(50 \% \mathrm{WP}), \quad$ tricyclazole (75\%WP), hexaconazole (5\%EC), propiconazole $(25 \% \mathrm{EC})$, thiophanate-methyl (70\%WP), copper-oxychloride (50\%WP) and mancozeb (75\%WP). Simultaneously different aqueous extracts $(1: 1 \mathrm{w} / \mathrm{v})$ of eight locally available botanicals namely turmeric (Curcuma longa), sweet flag (Acorus calamus), ginger (Zingiber officinale), simple leaf chaste tree (Vitex trifolia L.), Indianwormwood (Artemisia nilagrica), darrek (Melia azedarach), garlic (Allium sativum) and wild sedge (Lantana camera) were also evaluated at two level of concentrations against fungus $C$. fulvum associated with leaf mold of brinjal using poisoned food technique (Nene and Thapliyal, 1993).

The required quantity of each fungicide and prepared plant extracts were calculated for $50 \mathrm{ml}$ molten PDA medium to give the desired concentrations and shaken well to mix thoroughly. The poisoned PDA medium was poured in Petri plates@20ml per plate and allowed to solidify at room temperature. The plates were then inoculated aseptically with $5 \mathrm{~mm}$ disc taken from actively growing a 7 day-old culture of $C$. fulvum in an inverted position at the center of the plate.

The medium without any fungicide served as control and each treatment was replicated thrice. The growth of pathogen was recorded after 7 days of incubation and per cent inhibition on growth over control was calculated by using the formula as described by Vincent (1927) and data was statistically analyzed.

$\mathrm{PI}=[(\mathrm{C}-\mathrm{T}) / \mathrm{C}] \times 100$

Where, $\mathrm{PI}=$ percent of inhibition, $\mathrm{C}=$ growth in control plates, $\mathrm{T}=$ growth in plates treated with fungicides.

The effect of fungicides on sporulation of fungus was estimated by cutting one $\mathrm{cm}$ square of the mycelial block was cut from the periphery and then mixed in $5 \mathrm{ml}$ sterile water. It was shaken vigorously for 5 minutes. From this suspension, $0.5 \mathrm{ml}$ was poured in a hemocytometer and counted the number of conidia per $\mathrm{ml}$. per cent inhibition on sporulation over control was calculated by using the above formula. 
Table.1 Effect of different aqueous plant extracts on growth and sporulation of fungus at different concentration

\begin{tabular}{|c|c|c|c|c|c|c|c|c|c|c|c|c|}
\hline \multirow{2}{*}{$\begin{array}{c}\text { Treatm } \\
\text { ents } \\
\text { No. }\end{array}$} & \multirow{2}{*}{$\begin{array}{l}\text { Treatments } \\
\text { Details }\end{array}$} & \multirow{2}{*}{$\begin{array}{l}\text { Plant } \\
\text { parts } \\
\text { used }\end{array}$} & \multicolumn{2}{|c|}{$\begin{array}{c}\text { Conc. } \\
(\%)\end{array}$} & \multicolumn{2}{|c|}{$\begin{array}{c}\text { Growth* } \\
(\mathbf{c m})\end{array}$} & \multicolumn{3}{|c|}{$\begin{array}{c}\text { Growth Inhibition over } \\
\text { control }(\%)\end{array}$} & \multicolumn{3}{|c|}{ Sporulation (cfu/ml) } \\
\hline & & & $\mathbf{I}$ & II & I & II & I & II & $\begin{array}{l}\text { Pooled } \\
\text { data }\end{array}$ & I & II & $\begin{array}{c}\text { Pooled } \\
\text { data }\end{array}$ \\
\hline $\mathrm{T}_{1}$ & Turmeric & Rhizome & 5 & 10 & $\begin{array}{c}6.07 \\
(2.56) \\
\end{array}$ & $\begin{array}{c}5.47 \\
(2.44) \\
\end{array}$ & 24.17 & 31.67 & 27.92 & 0 & 0 & 0 \\
\hline $\mathrm{T}_{2}$ & Sweet flag & Rhizome & 5 & 10 & $\begin{array}{c}6.00 \\
(2.55)\end{array}$ & $\begin{array}{c}5.57 \\
(2.46)\end{array}$ & 25.00 & 30.42 & 27.71 & 0 & 0 & 0 \\
\hline $\mathrm{T}_{3}$ & Ginger & Rhizome & 5 & 10 & $\begin{array}{l}5.70 \\
(2.49)\end{array}$ & $\begin{array}{c}5.43 \\
(2.44)\end{array}$ & 28.75 & 32.08 & 30.41 & 0 & 0 & 0 \\
\hline $\mathrm{T}_{4}$ & Darrek & Leaf & 5 & 10 & $\begin{array}{l}5.73 \\
(2.50) \\
\end{array}$ & $\begin{array}{l}5.60 \\
(2.47) \\
\end{array}$ & 28.33 & 30.00 & 29.16 & 0 & 0 & 0 \\
\hline $\mathrm{T}_{5}$ & $\begin{array}{l}\text { Simple leaf } \\
\text { chaste tree }\end{array}$ & Leaf & 5 & 10 & $\begin{array}{c}6.47 \\
(2.64)\end{array}$ & $\begin{array}{c}6.30 \\
(2.61) \\
\end{array}$ & 19.17 & 21.25 & 20.21 & 0 & 0 & 0 \\
\hline $\mathrm{T}_{6}$ & $\begin{array}{l}\text { Indian wood } \\
\text { worm }\end{array}$ & Leaf & 5 & 10 & $\begin{array}{c}6.00 \\
(2.54)\end{array}$ & $\begin{array}{c}5.73 \\
(2.50)\end{array}$ & 25.00 & 28.00 & 26.5 & 0 & 0 & 0 \\
\hline $\mathrm{T}_{7}$ & Garlic & Clove & 3 & 6 & $\begin{array}{c}1.20 \\
(1.30)\end{array}$ & $\begin{array}{c}0.00 \\
(0.71)\end{array}$ & 85.00 & 100 & 92.5 & 0 & 0 & 0 \\
\hline $\mathrm{T}_{8}$ & Wild sedge & Leaf & 15 & 20 & $\begin{array}{c}5.87 \\
(2.52) \\
\end{array}$ & $\begin{array}{c}5.83 \\
(2.52) \\
\end{array}$ & 26.67 & 27.08 & 26.87 & 0 & 0 & 0 \\
\hline $\mathrm{T}_{9}$ & Control & - & - & - & $\begin{array}{c}8.00 \\
(2.92)\end{array}$ & $\begin{array}{c}8.00 \\
(2.92) \\
\end{array}$ & 0.00 & 0.00 & 0.00 & $2 \times 10^{8}$ & $2 \times 10^{8}$ & $2 \times 10^{8}$ \\
\hline SE (d) \pm & & & & & $(0.15)$ & (0.13) & & & & & & \\
\hline $\mathrm{CD}_{0.05}$ & & & & & $(0.32)$ & $(0.28)$ & & & & & & \\
\hline
\end{tabular}

* Mean of three replications. Figures in parenthesis are $\sqrt{\mathbf{X}}+\mathbf{0 . 5}$ transformed values 
Table.2 Effect of fungicides on growth and sporulation of fungus at different level of concentration

\begin{tabular}{|c|c|c|c|c|c|c|c|c|c|c|c|}
\hline \multirow{2}{*}{$\begin{array}{l}\text { Treatm } \\
\text { ent No. }\end{array}$} & \multirow{2}{*}{ Treatments Details } & \multicolumn{2}{|c|}{$\begin{array}{l}\text { Conc. } \\
(\%)\end{array}$} & \multicolumn{2}{|c|}{$\begin{array}{l}\text { Growth* } \\
(\mathrm{cm})\end{array}$} & \multicolumn{3}{|c|}{$\begin{array}{l}\text { Growth Inhibition over } \\
\text { control }(\%)\end{array}$} & \multicolumn{3}{|c|}{ Sporulation (cfu/ml) } \\
\hline & & I & II & $\mathbf{I}$ & II & I & II & $\begin{array}{l}\text { Pooled } \\
\text { data }\end{array}$ & $\mathbf{I}$ & II & $\begin{array}{l}\text { Pooled } \\
\text { data }\end{array}$ \\
\hline $\mathrm{T}_{1}$ & $\begin{array}{l}\text { Carbendazim } \\
\text { WP) }\end{array}$ & 0.05 & 0.1 & $\begin{array}{l}1.73 \\
(1.49)\end{array}$ & $\begin{array}{l}1.20 \\
(1.30)\end{array}$ & 78.33 & 85.00 & 81.67 & 0 & 0 & 0 \\
\hline $\mathrm{T}_{2}$ & Tricyclazol (75 WP) & 0.05 & 0.1 & $\begin{array}{l}2.00 \\
(1.58)\end{array}$ & $\begin{array}{l}1.73 \\
(1.49)\end{array}$ & 75.00 & 78.33 & 76.67 & 0 & 0 & 0 \\
\hline $\mathrm{T}_{3}$ & $\begin{array}{l}\text { Copperoxychloride } \\
(50 \mathrm{WP})\end{array}$ & 0.1 & 0.2 & $\begin{array}{l}3.47 \\
(1.99)\end{array}$ & $\begin{array}{l}2.10 \\
(1.61)\end{array}$ & 56.67 & 73.75 & 65.21 & 0 & 0 & 0 \\
\hline $\mathrm{T}_{4}$ & Hexaconazole (5 EC) & 0.05 & 0.1 & $\begin{array}{l}1.70 \\
(1.48) \\
\end{array}$ & $\begin{array}{l}0.20 \\
(0.82)\end{array}$ & 78.75 & 97.50 & 88.13 & 0 & 0 & 0 \\
\hline $\mathrm{T}_{5}$ & $\begin{array}{l}\text { Propiconazole } \quad(25 \\
\text { EC) }\end{array}$ & 0.05 & 0.1 & $\begin{array}{l}0.00 \\
(0.71)\end{array}$ & $\begin{array}{l}0.00 \\
(0.71)\end{array}$ & 100 & 100 & 100 & 0 & 0 & 0 \\
\hline $\mathrm{T}_{6}$ & $\begin{array}{l}\text { Thiophenate methyl } \\
(70 \mathrm{WP})\end{array}$ & 0.05 & 0.1 & $\begin{array}{l}1.80 \\
(1.52)\end{array}$ & $\begin{array}{l}1.23 \\
(1.32)\end{array}$ & 77.50 & 84.58 & 81.04 & 0 & 0 & 0 \\
\hline $\mathrm{T}_{7}$ & Mancozeb (75 WP) & 0.1 & 0.2 & $\begin{array}{l}1.87 \\
(1.54)\end{array}$ & $\begin{array}{l}1.57 \\
(1.44)\end{array}$ & 76.67 & 80.42 & 78.55 & 0 & 0 & 0 \\
\hline $\mathrm{T}_{8}$ & Control & - & - & $\begin{array}{l}8.00 \\
(2.92)\end{array}$ & $\begin{array}{l}8.00 \\
(2.92)\end{array}$ & 0.00 & 0.00 & 0.00 & $2 \times 10^{8}$ & $2 \times 10^{8}$ & $2 \times 10^{8}$ \\
\hline SE $(d) \pm$ & & & & $(1.83)$ & $(0.29)$ & & & & & & \\
\hline $\mathrm{CD}_{0.05}$ & & & & $(3.20)$ & $(0.62)$ & & & & & & \\
\hline
\end{tabular}

*Mean of three replications. Figures in parenthesis are $\sqrt{\mathbf{X}}+\mathbf{0 . 5}$ transformed value 


\section{Results and Discussion}

Data presented in table1 showed that there was a considerable range of efficacies of aqueous extracts at two different concentrations against growth and sporulation of the fungus. Garlic at 3\% showed $85 \%$ inhibition and $100 \%$ inhibition at $6 \%$. Remaining plant extracts showed less than $35 \%$ inhibition of growth of the fungus in both the concentrations.

All the fungicides evaluated in vitro against the radial growth of the fungus were found highly effective. The fungus was found $100 \%$ inhibition in propiconazole at both lower $(0.05 \%)$ and higher $(0.1 \%)$ concentrations. In the case of hexaconazole, there were $78.75 \%$ and $97.58 \%$ inhibition of radial growth of the fungus at 0.05 and $0.1 \%$ concentrations respectively (Table 2). Further, it was observed that all the fungicides could inhibit more than $70 \%$ at higher concentration. Copperoxychloride showed the least inhibition over the control. The sporulation of the fungus was completely inhibited (100\%) in all the treatments evaluated against fungus.

Among the eight plant extracts tested against the mycelial growth of $C$. fulvum, garlic aqueous extracts could inhibit 85.00 and $100 \%$ at 3 and $6 \%$ concentrations. However, it was observed that turmeric, chaste tree, sweet flag, ginger, dark, Indian wormwood and wild sedge could inhibit less than $35 \%$ of the fungal mycelial growth in both the concentrations evaluated and sporulation was completely inhibited. The effectiveness of garlic might be due to antifungal activity of allicin, diallyl-disulphide, diallyl-trisulphide and ajoene. The results were in accordance with the findings of Wei et al., (2010) who reported that garlic bulb crude extract at $40 \mathrm{mg}$ $\mathrm{ml}^{-1}$ could inhibit mycelia growth completely. Some of the aqueous plant extracts evaluated against the fungus under in vitro revealed that higher doses were relatively more efficient than the lower doses. This statement is in agreement with the findings of Shivpuri et al., (1997) also observed that effectiveness of plant extracts at higher doses than a lower dose of the 10 plant species evaluated.

The radial growth of $C$. fulvum was completely inhibited (100\%) by propiconazole $(0.05$ and $0.1 \%)$ followed by hexaconazole (78.75 and $97.58 \%$ ) at 0.05 and $0.1 \%$ concentrations. About $70 \%$ inhibitions on radial growth of the fungus were observed at higher concentrations of the fungicides evaluated and fungus could not sporulate at all in all the fungicides evaluated. The inhibitory effect of fungicides might be due to inhibition of sterol biosynthesis and activities of cell division and mitosis and contact multisite activities. The present findings were in association with the findings of Jordan et al., (1990) who reported that propiconazole and triademafone could inhibit the growth of Cladosporium alli-cepae and C. alli at $100 \mu \mathrm{g}$ ai $/ \mathrm{ml}$.

For effective management of brinjal leaf mold disease propiconazole $(0.05 \%)$ was found to be most effective. Among the plant extracts garlic $(6 \%)$ has shown the maximum control of the disease. All the plant extracts had shown significant efficacy in managing fungus in vitro. The plant extracts can be used directly for organic farming practices and can also be integrated into IDM.

\section{References}

Anonymous, 2016. Horticulture statistics at a glance 2015. National Horticulture Board. Oxford University Press. Pp: 151.

Chaudhary, B., 1976. Vegetables, 4th edn., National Book Trust, New Delhi, pp. 50-58.

Doganlar, S., Frary, A., Daunay, M.C., Lester, R.N. and Tanksley, S.D. 2002. A comparative genetic linkage map of 
eggplant (Solanum melongena) and its implications for genome evolution in the Solanaceae. Genetics, 161: 17131726.

Jordan, M.M., Maude, R.B., Burchill, R.T. 1990. Tests of fungicides for the control of leaf blotch diseases: Cladosporium allii of leek and $C$. allii-cepae of onion. Crop Prot., 9(5): 367-370.

Mishra, A.K., and Mishra, V.K. 2012. Field survey for some fungal diseases on eggplant. Intern. Multidiscip. Res. J., 2(9): 23.

Nene, Y.L., Thapliyal, P.N. 1993. Fungicides in plant disease control. Oxford and IBH, Pub. Col. New Delhi. pp. 1-501.

Pandey, A. and Pandey, B.N. 2001. Fungal diseases on brinjal in Bareilly region. Advance. Plant Sci., 14(1): 99-104.

Prashant, Tombisana Devi, R. K., Iboton Singh, N., and Murasing, A. 2017. Survey on brinjal leaf mold in Manipur and proving its Pathogenicity. Int. J.
Curr. Microbiol. App. Sci., 6(6): 10701073.

Shivpuri, A., Sharma, O.P., and Jhamaria, S.L. 1997. Fungitoxic properties of some plant extract against pathogenic fungi. J. Mycol. Plant Pathol, 27(1): 29-31.

Tomar, B.S., and Kalda, J.S. 1998. Production system. Is eggplant nutritious? TVIS Newsletter, 1(1): 26.

Tutte, J., 1969. Plant pathological methods Fungi and bacteria. Burgess publishing company, U.S.A., pp 229.

Vincent, J.M., 1927. Distortion of fungal hyphae in presence of certain inhibitors. Nature, 159: 850.

Wei, T.T., Cheng, Z.H., Ma, Q. and Han, L. 2010. The inhibitive effects of the garlic bulb crude extract on Fulvia fulva of tomato. International symposium on organic horticulture: productivity and sustainability. Acta Hortic, pp. 933.

\section{How to cite this article:}

Prashant, R.K. Tombisana Devi and Iboton Singh, N. 2017. In vitro Efficacy of Different Botanicals and Fungicides on Brinjal Leaf Mold Pathogen. Int.J.Curr.Microbiol.App.Sci. 6(9): 2465-2470. doi: https://doi.org/10.20546/ijcmas.2017.609.304 